\title{
Sciendo
}

DOI: $10.2478 /$ jolace-2018-0027

\section{Opportunities to Develop Intercultural Communicative Competence in Czech lower-secondary schools: Findings of the IRSE Video Study of German}

\author{
Jana Zerzová \\ Masaryk University in Brno, Czech Republic \\ zerzova@mail.muni.cz
}

\begin{abstract}
The empirical study deals with the topic of teaching intercultural communicative competence (ICC) in Czech lower-secondary German classes. The aim of the study is to investigate the quantity and quality of the opportunities to develop ICC, the proportion of activities aimed at developing the cognitive, affective, and behavioural component of ICC, the proportion of activities focused on Big-C Culture and small-c culture and culture-general and culture-specific topics. The introductory part and the following part of the study introduce its theoretical background, and terminology is then followed by the methodological part describing the sample $(28$ German lessons of 7 teachers videotaped in the $8^{\text {th }}$ and $9^{\text {th }}$ grades of Czech lower-secondary classes at seven schools in Jihomoravský region within the IRSE Video Study of German ${ }^{1}$ project), the way of processing the data (recording, transcription, coding), the research questions and a system of categories (a system for assessing teaching ICC), that was used for analyses of the videotaped lessons. The findings show that emphasis is put on the cognitive component of ICC, while the other components (behavioural and affective) stay at the background. These results are consistent with the results of the IRSE Video Study of English project (Zerzová, 2012), which has the potential of initiating discussion for both English and German language teaching methodologies.
\end{abstract}

Key words: German, foreign language, ICC, intercultural competence, intercultural communicative competence, opportunities to learn, system of categories, video study

\section{Introduction}

The study focuses on the development of intercultural communicative competence (ICC) in foreign language teaching (FLT), more specifically in German language teaching (GLT). It builds upon a previously conducted research that focused on the development of ICC in English classes that was published under the

1 The IRSE Video Study of German is a research project of the IRSE Video Study carried out in the Institute for Research in School Education at the Faculty of Education of Masaryk University in Brno. 
IRSE Video Study of English project (Zerzová, 2012), and draws from previously published studies on this topic (Zerzová, 2012; Zerzová \& Šebestová, 2014), since its aim is to present parallel research of GLT with focus on ICC development.

Acquiring ICC, whose outer demonstration is the ability to communicate effectively across cultures in a socially and culturally sensitive way, is considered essential in the $21^{\text {st }}$ century to avoid conflicts rooted primarily in cultural difference (Huntington, 1996).

FLT offers specific opportunities to develop ICC, although curricular documents do not reflect this reality sufficiently (see Zerzová, 2012), yet they do cover the need to gain knowledge about foreign cultures, develop pupils' skills and attitudes towards their own and foreign cultures and their interaction to some extent.

The study presented in this paper therefore aims to examine how the development of ICC is realized in GLT. It investigates the quantity and quality of the opportunities to develop ICC, the proportion of activities aimed at developing the cognitive, affective, and behavioral component of ICC, the proportion of activities focused on Big-C Culture and small-c culture and culture-general and culture-specific topics

\section{Theoretical background}

\subsection{Opportunities to learn}

The aim of the IRSE Video Study of English was to conduct explorative analyses of the teaching processes and document, describe and analyze the ELT process at lower-secondary schools in the Czech Republic. The IRSE Video Study of German has the same aims and therefore the same theoretical foundation.

The IRSE Video Study project as a whole follows the concept of opportunities to learn (Lerngelegenheiten) that was designed as a theoretical foundation that would enable examination of the process of teaching in its complexity (McDonnell, 1995). Opportunities to learn enable researchers to examine the potential of teaching from the perspective of support for pupils' learning, namely from two standpoints: (a) opportunities to learn offered by the teaching and (b) opportunities to learn utilized by pupils. From the methodological perspective, there are two ways that can be applied to examine opportunities to learn: (a) quantitative: opportunities to learn as the amount of time (Carroll, 1963); (b) qualitative: what the pupils learn is dependent on the quality of what is offered to them in the teaching process (Doyle, 1983; Hiebert \& Wearne, 1993).

According to Najvar et al. (2011, p. 90, author's translation), „,school education should primarily focus on creating opportunities, in which the pupils would not only acquire subject matter, but would be able to draw on it and use it in particular situational contexts". Opportunities to learn are then understood as the interaction process between the teacher and the pupils and the pupils among themselves, that 
creates the potential for co-creation of opportunities to learn. The research presented in this study then focuses on the observable activity of the pupils in the teaching process, in which the pupils' ICC may be developed.

\subsection{Intercultural Communicative Competence}

Competence is understood as a holistic (cf. e.g. Píšová, 2005), complex umbrella term composed of skills, knowledge, and comprising attitudes and values of an individual (cf. Kubeš et al., 2004; Maňák, 2007; Skalková, 2007, etc.).

Byram's intercultural communicative competence (1997) is preferred to other terms so that the complexity of this term is stressed and connection to FLT made clear. The aim in developing ICC is using the target language, or secondarily the mother tongue, actively in a socially sensitive way in intercultural interaction, not mere development of ICC in the mother tongue. The development of ICC should primarily be conducted in the target language (cf. Fantini, 2006).

An analysis of ICC models with the purpose of didactization of ICC in the context of assessment of ICC development was published by Kostková (2012); numerous models were introduced by Zerzová (2012) with the same purpose in the context of realized curriculum and analysis of the process of ICC development based on lesson observations.

For analyses focusing on the intercultural component of ICC that preceded this study (Zerzová, 2012), a model that illustrates didactic aspects of ICC was constructed (Figure 1) that might be used in the context of teaching and research of teaching.

The model that was constructed and used in this research defines target areas of ICC development which a system of categories for observation and analysis of the teaching process builds upon. The model is set in the context of FLT and stresses the intercultural component above the communication component, although they cannot be strictly separated. ${ }^{2}$

When the model was being constructed, we took existing ICC models into account, many of which define cognitive, behavioural, and affective component of ICC and formulate specific aims in each of these areas in form of knowledge, skills, attitudes and values (see Zerzová, 2012; Kostková, 2012). Further, the difference between culture-general and culture-specific goals was reflected (cf. Paige et al., 1999 as cited in Göbel, 2007, p. 46; Bennett, Bennett, \& Allen 2003) as well as the

2 Knowledge of a foreign language is understood to be an influential factor in the development of ICC of an individual (cf. Fantini, 2006). However, in our opinion, it cannot be stated that lessons led in the mother tongue aiming at the development of one of the ICC components cannot contribute to the development of the communication component in any way. Research that would cover this area is absent. 
difference between Big-C Culture and small-c culture ${ }^{3}$. As a result, eight target areas of ICC development came into being (Figure 1).

\section{Didactic aspects}

Cultural Disengagement
Adaptation
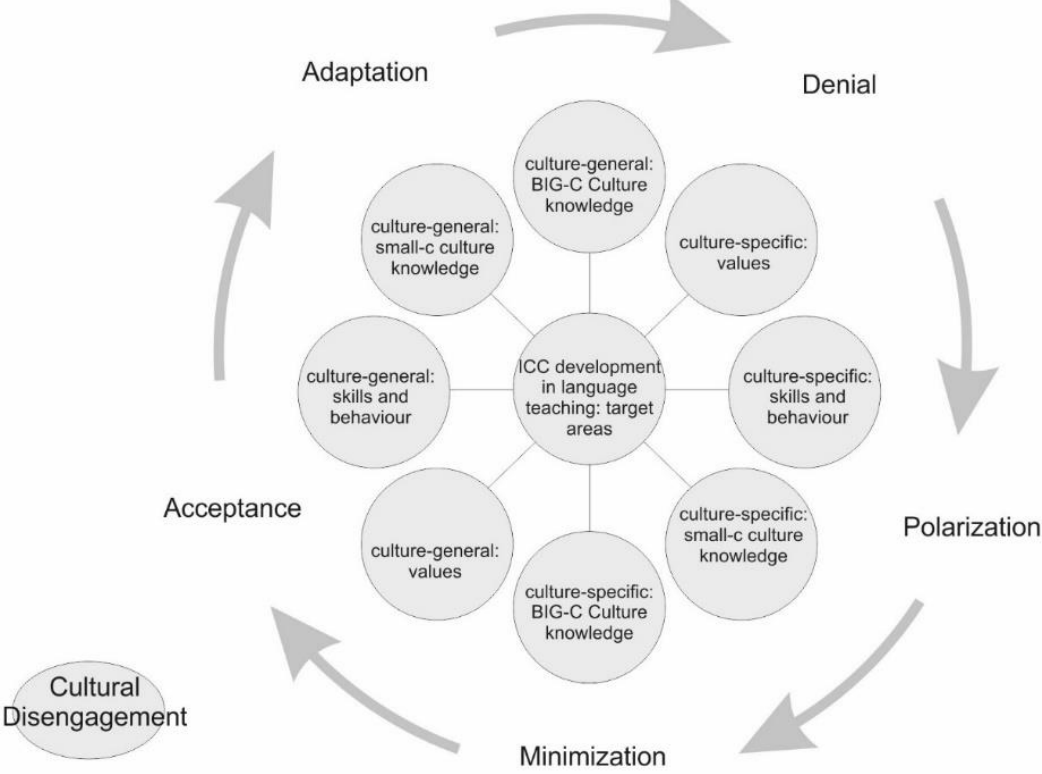

Figure 1: Didactic Aspects of ICC development (Zerzová, 2012, author's translation)

${ }^{3}$ Big-C Culture is often referred to as Upper-Case Culture, achievement culture, Culture 1 or objective culture, whereas small-c culture as lower-case culture, behavioral culture, Culture 2 or subjective culture (cf. Triandis, 1989; Stern, 1992; Tomalin \& Stempleski, 1993; Bennett, 1998; Bennett, Bennett, \& Allen, 2003; Hofstede \& Hofstede, 2005). Big-C Culture includes primarily knowledge from the fields of history, geography, literature, arts, institutions, politics, etc. Small-c culture according to Bennett (1998) includes psychological traits that define a certain group of people - their everyday thinking patterns and actions - rather than institutions they created. However, it does not only include knowledge about aspects of everyday life of people of a certain culture, but also development of a wide range of skills and attitudes - i. e. the affective and behavioural component of ICC. Although these two terms are usually presented in a dichotomous relationship, it is obvious that they need to be understood as a continuum and that it is done for the simplification and explanation of these two concepts. 
The tendency to leave ethnocentrism and the traditional concept of teaching culture is a common tendency in FLT. Not only the English language that functions as the modern lingua franca, but also other languages (e.g. German, Russian, and French) represent various cultures and play the role of an international communication tool. Therefore, there is a visible tendency in the Anglophone, Germanophone, and Francophone areas to change the teaching aims from mere knowledge transmission to communication development, and finally development of intercultural awareness and ICC. Focus on the target language countries only is perceived as insufficient for ICC development (cf. Langner et al., 1990; Kramsch, 1993; Buttjes, 1995; Seletzky, 1996; Byram, 1997; Timm, 1998; Nünning \& Nünning, 2000).

We find parallels in the Germanophone area to the Anglophone area. The so called intercultural approach (interkultureller Ansatz) became a leading concept over the cognitive approach (kognitiver Ansatz) and communicative approach (kommunikativer Ansatz) with focus on higher aims in form of understanding a foreign culture instead of mere knowledge transmission about a particular country (as in kognitiver Ansatz) or its everyday culture (as in kommunikativer Ansatz). However, focus on the target language countries was still prevalent in this approach (cf. Weimann \& Hosch, 1991, as cited in Pauldrach, 1992, p. 6) and started being abandoned with the emission of the so called ABCD theses (ABCDThesen, 1990) that stated goals for intercultural German language teaching with the aim of leaving simplified culture interpretations, eliminating prejudice and developing understanding across nations (cf. Langner et al., 1990). Obviously, the cognitive approach (kognitiver Ansatz) and the communicative approach (kommunikativer Ansatz) can be partially viewed as parallel to the Big-C Culture and small-c culture dichotomy.

Developing intercultural awareness may be perceived as central do ICC development ${ }^{4}$, however, it is not set aside as a separate target area in our ICC model, but stays 'hidden' (especially in the form of one's own culture awareness and awareness of other cultures) in five development phases of ICC represented in the model by arrows (Denial, Polarization, Minimization, Acceptance, Adaptation). Language teachers can focus on these phases and combine them with the eight target areas. These development phases are based on Bennett's Developmental Intercultural Competence Model/Developmental Model of Intercultural Sensitivity: DMIS (1986) and Intercultural Development Inventory: IDI, v. 3 that was designed based on it (Hammer, 2009). It is a model that perceives IC holistically, focuses on definition of the individual IC development phases and views an individual on an

\footnotetext{
4 For more on awareness in ICC models see Kostková (2012) and her ICC model including attitudes, skills, awareness, and knowledge where foreign language competence forms a fifth important component of ICC, in which the other four dimensions are embed.
} 
intercultural competence development continuum starting with ethnocentric phases (Denial, Polarization), containing a transitional phase of Minimization and ending with ethnorelative phases of Acceptance, Adaptation (cf. Bennett, 1986; Hammer, 2009). ${ }^{5}$

The system of categories designed for the purposes of the presented research and the research itself did not - considering the research design (i.e. observation of videotaped lessons, lessons of English and German videotaped as a whole) focus on the analysis of teaching from the perspective of these development phases but only on the opportunities to learn from the perspective of the eight target areas.

Therefore, only part of our ICC model was used. Using the Developmental Intercultural Competence Model and Intercultural Development Inventory: IDI for educational and research purposes in the Czech Republic is open for discussion in future research projects. It is also possible, that the ICC model will have to be revised when used in future research with different research design.

\subsection{Research of the quality of teaching ICC}

The number of research projects realized in the area of ICC development is limited. The results of our previous analyses (Zerzová, 2012) showed that teachers of English prefer to focus primarily on the cognitive component of ICC and the development of their pupils' knowledge in their teaching and neglect developing their skills, attitudes and values. These findings are consistent with the traditional teaching of culture. It seems that skills needed in the context of intercultural interactions are only addressed in a very limited extent and pupils' attitudes towards foreign cultures and interactions are not worked with systematically. The findings of the IRSE Video Study of German are identical (see Chapter 3).

If we were to compare our findings with other research, we find the scope of similar research is limited. Most models and tools testing ICC were designed out of language teaching context, which is necessarily reflected in research as well.

However, there were complex research projects conducted (in the USA, as well as in 25 European countries), that bring our attention to the fact that education does not prepare future teachers sufficiently either for intercultural interactions, or for teaching ICC itself (Dunnett et al., 1986; Met, 1993; Kelly, 2002; Guilherme, 2002; Sockett \& LePage, 2002; Lázár, 2003). Research conducted in the USA, Belgium, Great Britain, and Denmark shows that teachers lack a systematical plan of ICC development and covering pupils' prejudice in their lessons, as well as criteria that would help them differentiate their attitudes (Sercu, 2002b; Met, 1993). As a result, teachers are supposed to meet a number of educational goals

\footnotetext{
${ }^{5}$ For a brief description of these development phases and a separate dimension of cultural disengagement see Zerzová, 2012.
} 
that they do not feel competent to cover (Byram \& Morgan, 1994; Sercu, 2002a). The research only indirectly suggests how these findings may be reflected in the teaching practice, however it cannot be compared with research findings presented in this article.

A German video study project DESI (Deutsch Englisch Schülerleistungen International) included a partial research project in which Göbel (2007) focused on the quality of intercultural ELT. There had been no such research conducted till that time (cf. Göbel, 2007). The research design was different from that of the IRSE Video Study (10 videotaped lessons with given topics and specific teaching materials assigned), which means there can be no comparison made with the research presented in this study, although the focus of the research was unique.

The number of foreign research projects focusing on the ICC development in FLT is thus limited, and this is valid for the situation in the Czech Republic as well.

Numerous foreign and Czech research projects in the area of multicultural education focusing on attitudes, stereotypes and prejudice, intercultural differences across nations and attempts at measuring national and ethnic identity were described in Průcha's publications $(2001,2006)$. Bočánková (2006) studied intercultural communication processes and attitudes of university students, Navrátil (2002) focused on research of interethnic relationships, Hladík (2010) focuses in his research on multicultural competence and its dimensions. Kostková worked with university students of ELT and studied whether they develop ICC during their studies and if so, in which dimensions (Brebera \& Kostková, 2008; Kostková, 2010a, 2010b; Kostková, 2012). Pešková (2012) studied visuals for teaching culture in German language textbooks, Reid (2014) focused on intercultural aspects in teaching English at primary schools in the Slovak Republic, and Zerzová, Karpetová, and Šamalová (2017) examined cultural aspects of English as an international language in ELT textbooks. However, none of these represents empirical research of the quality of teaching ICC.

Czech School Inspectorate conducted an investigation in 2008/2009, in which they focused on presence of multicultural education and teaching culture in foreign language lessons (cf. Souhrnné poznatky o podpoře a rozvoji výuky cizích jazyků v předškolním, základním a středním vzdělávání v období let 2006-2009). 1,378 lessons at elementary schools and 671 lessons at secondary schools were observed and the findings show that aspects of multicultural education were present in $83 \%$ of lessons and teaching culture in $62 \%$ of lessons. The findings are not differentiated concerning the level of education or foreign language taught. The report does not state the criteria that were used to collect the data, which is very limiting, however the findings of both the IRSE Video Study of English and IRSE Video Study of German are in stark contrast to the findings of the Czech School Inspectorate. 


\section{Research - methodology}

\subsection{Methodology - research sample and data processing}

Data collection in IRSE Video Study of English was described in earlier publications (cf. Najvar et al., 2008, 2011), as well as the data collection in IRSE Video Study of German (Zlatníček, 2014). Therefore, we will only briefly present the basic information about the research sample.

28 German lessons of 7 teachers (1 male and 6 female teachers) were videotaped in the $8^{\text {th }}$ and $9^{\text {th }}$ grades of Czech lower-secondary classes at seven schools in Jihomoravský region. The lessons were videotaped in a standardized way (Janík \& Miková, 2006) using two video cameras - one focusing on the activity of the pupils, and one focusing on the activity of the teacher. Videograph ((Rimmele, 2002) was used to process the data.

The data presented in the findings are transcribed in a standardized way (Seidel et al., 2003; Janík \& Miková, 2006), presenting utterances of the teacher (T), pupil (P), several pupils (PP), or the whole class (C), in 10-second intervals, including sequences in which audio recordings were used (CD). When there is an unintelligible sequence, the symbol $(0$ is used, in case of simultaneous speech, the symbol // is used.

\subsection{Methodology - research questions}

The main aim of both the IRSE Video Study of English (Zerzová, 2012) and German (presented in this article) was investigating the time dimension of ICC development, which is consistent with the overall concept and theoretical outcome of teaching as creating opportunities to learn.

Further, the analyses focused on the quality of teaching dimension - i.e. quality of the opportunities to learn from the perspective of the ICC development and its cognitive, behavioural, and affective component, Big-C Culture and small-c culture, and culture-general and culture-specific topics. A system of categories was constructed to code the gathered data (2.3.1).

The following research questions were derived from the main research aim:

1 Frequency of opportunities to develop ICC in German language teaching

1a) What is the time dimension of activities aimed at developing ICC?

2 Quality of opportunities to develop ICC in German language teaching

2a) What is the ratio of activities aimed at developing the cognitive, behavioural, and affective dimension of ICC?

2b) What is the ratio of activities covering BIG-C Culture and small-c culture?

2c) What is the ratio of activities covering culture-general and culture-specific topics? 


\subsection{Methodology - System of categories for Assessing Teaching ICC}

For the purposes of the analyses a system of categories was designed that contains ten categories (see Table 1). These are divided into culture-general and culture-specific according to Paige et al. (1999, as cited in dle Göbel, 2007, p. 46 and Bennett, Bennett, \& Allen, 2003). In both of these there are four parallel categories reflecting the cognitive, behavioural, and affective components of ICC. The Big-C Culture and small-c culture dichotomy is also reflected in the system.

Categories 1 and 5 (BIG-C Culture knowledge) reflect the cognitive component of ICC and the Big-C Culture concept. Categories 2, 3, 4, 6, 7, and 8 refer to the smallc culture concept, while categories 2 and 6 (small-c culture knowledge) only cover the cognitive component of small-c culture, whereas categories 3 and 7 (skills/behaviour) refer to the behavioural dimension of ICC and categories 4 and 8 (values) to the affective dimension of ICC.

Category 0 (none) refers to a phase before or after the lesson. The last category (9) is used for a phase of a lesson that is not relevant for developing the intercultural component of ICC. The individual categories are briefly described in Table 1 (for more see Zerzová, 2012).

\begin{tabular}{|c|c|c|c|c|}
\hline No & Category & Domain & $\begin{array}{l}\text { BIG-C } \\
\text { CULTURE/ } \\
\text { small-c } \\
\text { culture }\end{array}$ & Brief description \\
\hline $\mathbf{0}$ & none & - & - & $\begin{array}{l}\text { Sequences before or after the } \\
\text { lesson. }\end{array}$ \\
\hline 1 & $\begin{array}{l}\text { culture-general: } \\
\text { BIG-C CULTURE } \\
\text { knowledge }\end{array}$ & cognitive & $\begin{array}{l}\text { BIG-C } \\
\text { CULTURE }\end{array}$ & $\begin{array}{l}\text { Teaching sequences aimed at } \\
\text { knowledge from the fields of } \\
\text { history, geography, literature, } \\
\text { art, politics, industry, etc. that } \\
\text { are not connected to only one } \\
\text { country or e.g. Anglo-American } \\
\text { culture but cover a more general } \\
\text { level (e.g. European Union, } \\
\text { global). }\end{array}$ \\
\hline 2 & $\begin{array}{l}\text { culture-general: } \\
\text { small-c culture } \\
\text { knowledge }\end{array}$ & cognitive & $\begin{array}{l}\text { small-c } \\
\text { culture }\end{array}$ & $\begin{array}{l}\text { Teaching sequences aimed at } \\
\text { knowledge of facts and } \\
\text { information connected to } \\
\text { everyday life, life style and } \\
\text { differences and similarities } \\
\text { across cultures on a more } \\
\text { general level (aspects common } \\
\text { for more cultures, not only one } \\
\text { nation), as well as general } \\
\text { concepts-e.g. culture shock. }\end{array}$ \\
\hline
\end{tabular}




\begin{tabular}{|c|c|c|c|c|}
\hline 3 & $\begin{array}{l}\text { culture-general: } \\
\text { skills/behaviour }\end{array}$ & behavioural & $\begin{array}{l}\text { small-c } \\
\text { culture }\end{array}$ & $\begin{array}{l}\text { Teaching sequences devoted to } \\
\text { topics from the field of } \\
\text { sociolinguistics covering a more } \\
\text { general level, lifestyle and } \\
\text { everyday life topics, acquiring } \\
\text { intercultural learning } \\
\text { strategies, acquiring strategies } \\
\text { to reduce stress when in touch } \\
\text { with foreign cultures, } \\
\text { interpretation skills and finding } \\
\text { connections, searching for } \\
\text { information, etc. }\end{array}$ \\
\hline 4 & $\begin{array}{l}\text { culture-general: } \\
\text { values }\end{array}$ & affective & $\begin{array}{l}\text { small-c } \\
\text { culture }\end{array}$ & $\begin{array}{l}\text { Teaching sequences aimed at } \\
\text { developing positive attitudes to } \\
\text { foreign cultures, learning about } \\
\text { foreign cultures, developing } \\
\text { sympathy and tolerance, } \\
\text { examining pupils' experience, } \\
\text { developing willingness to } \\
\text { interact in a foreign language, } \\
\text { discussing stereotypes, bias and } \\
\text { generalizations, etc. }\end{array}$ \\
\hline 5 & $\begin{array}{l}\text { culture-specific: } \\
\text { BIG-C CULTURE } \\
\text { knowledge }\end{array}$ & cognitive & $\begin{array}{l}\text { BIG-C } \\
\text { CULTURE }\end{array}$ & $\begin{array}{l}\text { Teaching sequences aimed at } \\
\text { knowledge from the fields of } \\
\text { history, geography, literature, } \\
\text { art, politics, industry, etc. that } \\
\text { are connected to only one } \\
\text { country or e.g. Anglo-American } \\
\text { culture. }\end{array}$ \\
\hline 6 & $\begin{array}{l}\text { culture-specific: } \\
\text { small-c culture } \\
\text { knowledge }\end{array}$ & cognitive & $\begin{array}{l}\text { small-c } \\
\text { culture }\end{array}$ & $\begin{array}{l}\text { Teaching sequences aimed at } \\
\text { knowledge of facts and } \\
\text { information connected to } \\
\text { everyday life, life style, and } \\
\text { customs of specific (not only } \\
\text { target) countries and cultures, } \\
\text { taboos of specific (not only } \\
\text { target) cultures, ways of gaining } \\
\text { information about e.g. target } \\
\text { cultures, etc. }\end{array}$ \\
\hline 7 & $\begin{array}{l}\text { culture-specific: } \\
\text { skills/behaviour }\end{array}$ & behavioural & $\begin{array}{l}\text { small-c } \\
\text { culture }\end{array}$ & $\begin{array}{l}\text { Teaching sequences devoted to } \\
\text { topics from the field of } \\
\text { sociolinguistics dealt with in the } \\
\text { form of practice in the target } \\
\text { language or aimed at developing } \\
\text { interpretation skills, finding }\end{array}$ \\
\hline
\end{tabular}




\begin{tabular}{|c|c|c|c|c|}
\hline \multicolumn{2}{|c|}{ JoLaCE } & \multicolumn{3}{|c|}{$\begin{array}{r}\text { Journal of Language and Cultural Education, 2018, 6(3) } \\
\text { ISSN 1339-4584 } \\
\text { SlovakEdu }\end{array}$} \\
\hline & & & & $\begin{array}{l}\text { similarities, searching for } \\
\text { information, etc. }\end{array}$ \\
\hline 8 & $\begin{array}{l}\text { culture-specific: } \\
\text { values }\end{array}$ & affective & $\begin{array}{l}\text { small-c } \\
\text { culture }\end{array}$ & $\begin{array}{l}\text { Teaching sequences aimed at } \\
\text { developing positive attitudes to } \\
\text { a specific (e.g. target) culture } \\
\text { and its customs, developing } \\
\text { tolerance of specific aspects of } \\
\text { other countries, comparisons } \\
\text { with one's own culture. }\end{array}$ \\
\hline 9 & other & - & - & $\begin{array}{l}\text { Teaching sequences that cannot } \\
\text { be classified as any of the above } \\
\text { mentioned categories. E.g. } \\
\text { sequences devoted to } \\
\text { grammatical, lexical, spelling or } \\
\text { pronunciation exercises, etc. }\end{array}$ \\
\hline
\end{tabular}

Tab. 1: System of Categories for Assessing Teaching ICC

\section{Selected findings}

\subsection{Frequency of opportunities to develop ICC in German language teaching}

The findings show that the amount of time devoted to developing ICC of the pupils was $10 \%$ of the total teaching time, i.e. 118 minutes and 50 seconds. This is identical with the results of the IRSE Video Study of English (Zerzová, 2012). In 50\% of the lessons (14 out of 28) there were no categories present other than Category 9 (other). Graph 1 illustrates the representation of the categories with the individual teachers. The most frequently represented category was Category 5 (culture-specific: BIG-C CULTURE knowledge) with 64 minutes and 40 seconds, and Category 1 (culture-general: BIG-C CULTURE knowledge) with 48 minutes and 20 seconds. Category 6 (culture-specific: small-c culture knowledge) was represented with 5 minutes, and Category 7 (culture-specific: skills/behaviour) with 50 seconds. It is obvious, that the focus on the cognitive component of ICC is prevalent, which is consistent with the results of the IRSE Video Study of English (Zerzová, 2012).

\subsection{Quality of opportunities to develop ICC in German language teaching}

As mentioned above, the cognitive component of ICC was prevalent in the research sample (118 minutes). The behavioural component of ICC was represented with 50 seconds in two lessons (30 seconds in lesson A4 and 20 seconds in lesson B3) and the affective component of ICC was not represented at all. However, it is interesting that $57 \%$ of the teaching time devoted to developing ICC (48 minutes and 20 seconds) covered culture-general topics, which is in 
discrepancy with the findings of the IRSE Video Study of English where $92 \%$ of the teaching time devoted to developing ICC was focused on culture-specific topics. $B I G-C$ Culture was represented with $57 \%$ of the teaching time devoted to developing ICC (48 minutes and 20 seconds).

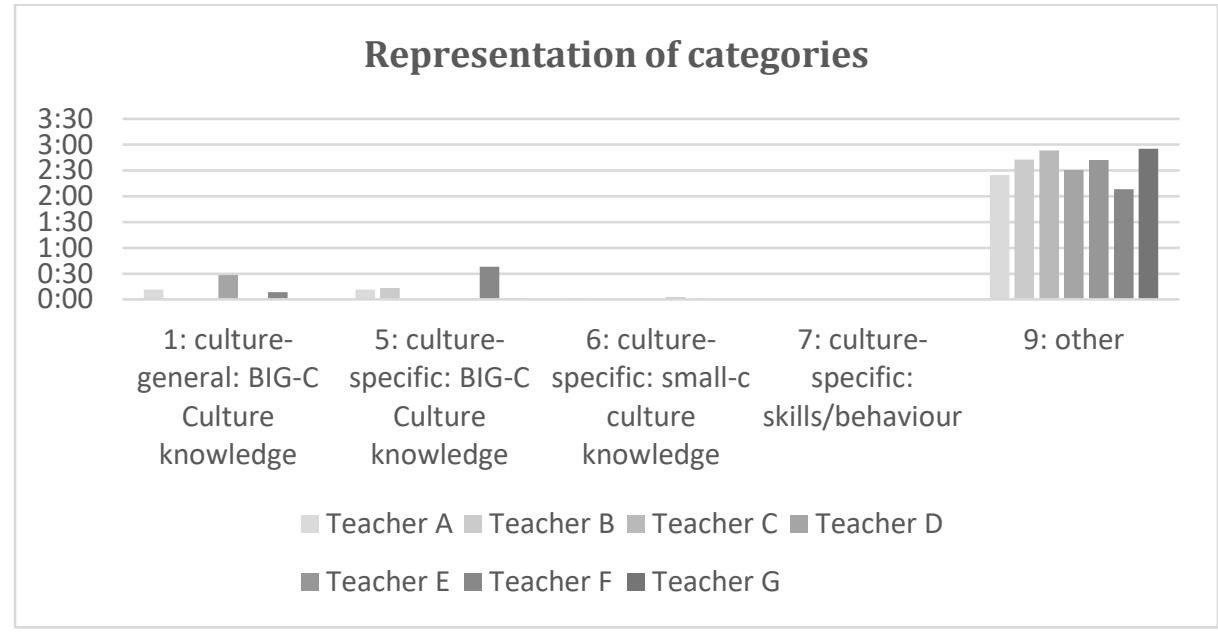

Graf 1: Representation of the categories in half-hours in lessons of the individual teachers

Extracts of transcripts from the lessons follow to illustrate how the individual categories are represented in GLT. The study does not aspire to present only instances of good practice but rather attempts to illustrate the variety of teaching practice.

\subsubsection{Category 1: culture-general: BIG-C Culture knowledge}

This category was coded in 3 lessons. Lesson A1 covered famous people and facts about them having pupils match information about them to their photographs and present the information to their classmates (11 minutes 30 seconds), lesson D2 focused on matching countries with continents and listening to a recording of a letter from a friend describing his travel plans (28 minutes 30 seconds) and F1 also covered matching countries with the continents and a listening to check the answers ( 8 minutes 20 seconds).

Table 2 shows and extract from lesson F1 in which a student is supposed to match a country with the continent on the blackboard. 
00:04:50 - 00:05:00

T: Also, sie verbinden, eh, Iva, ein Land, eh, mit, eh, einem Kontinent, ja?

Takže tady máme nahoře

00:05:00 - 00:05:10

T: Kontinenty a //

$P: / /()$

T: dobře, hm [ano]. A ř́kejte to nahlas! Takže Ty jsi spojila //

P: // Č́na a Asie

T: Čína, takže řekni Čína

00:05:10 - 00:05:20

T: je v Asii.

P: Čina ist

T: China - China, jo? Se to čte. Ist

P: China ist

Knocking on the door and a pupil entering the classroom.

P: Dobrý den.

00:05:20 - 00:05:30

P: China ist im Asien.

T: Im Asien, hm [ano].

Table 2: Transcript from lesson F1 - Category 1: culture-general: BIG-C Culture knowledge

\subsubsection{Category 5: culture-specific: BIG-C Culture knowledge}

In lesson A1 the pupils were supposed to put pieces of a fairy tale (Little Red Riding Hood) together and then read it aloud (11 minutes 30 seconds), in C3 they covered where Holzkirchen is (20 seconds), in lesson F3 the teacher prepared a PowerPoint presentation about Vienna including pictures from the pupils' trip to Vienna, exercises using the interactive whiteboard and covered facts about Vienna, names of Vienna in different languages, the personality of Maria Theresa, famous places and memorials in Vienna, etc. (38 minutes 20 seconds). In G1 the pupils learned what Adlergebirge is (10 seconds) and in G3 what the capital of the Czech Republic is ( 1 minute 10 seconds). The extract is from lesson B4 (13 minutes 10 seconds) in which the pupils were listening to a recording of classical music and then working with the textbook and a map on the board, discussing Salzburg and its monuments and reading correspondence between friends from the textbook.

The pupils are listening to a recording of classical music.

00:31:10-00:31:20

T: Was war das?

PP: Mozart!// 
T: // Mozart. Wisst ihr was von Mozart?

P: Figarova svatba.

T: Ee [ne].

00:31:20-00:31:30

$P P:()$

00:31:30-00:31:40

T: Mozartova?

P: Maryša!

PP: Laughing. Magor! Ma ma ma ma (singing)

00:31:40-00:31:50

T: V Čechách jsme, Ríšo! Malá//

ZZ: //

T: noční

00:31:50-00:32:00

T: hudba. Eine kleine Nachtmusik, ja? Also, wir sollen heute ein wenig über Mozart sprechen.

00:32:00-00:32:10

T: Eh, wo ist Mozart geboren? Kde se narodil? Víme?

PP: Österreich.

T: Im Salzburg//

PP: //m Salzburg

T: aber

00:32:10-00:32:20

T: er lebte fast das ganze Leben im Wien. Narodil se v Salzburku, ale žil většinu života ve Vídni.

Table 3: Transcript from lesson B4 - Category 5: culture-specific: BIG-C Culture knowledge

\subsubsection{Category 6: culture-specific: small-c culture knowledge}

This category was represented in lesson E2 (1 minute 20 seconds) with the teacher's explanation of how to use the expression „Wie geht's dir?" and how to react to it. However, the pupils did not practice it. In E3 (1 minute) the topic was the same and the pupils were discussing with the teacher how to correctly respond to a test item and what kind of answers were acceptable in the test. They came up with possible reactions to „Wie geht's dir?" - "Sehr gut!", "Prima”, "Nicht so gut”, "Nicht so schlecht" but did not practice them.

In lesson F2 (40 seconds) the teacher covered the difference between the German and Austrian greeting ('Guten Tag' versus 'Grüss Got') but the pupils again did not put it into practice. 
In lesson A2 (1 minute 30 seconds) the teacher discussed types of schools in Germany and in A1 (20 seconds) the difference between the word 'Dame' and 'Frau' was explained by the teacher.

00:36:10 - 00:36:30:

T: To je spíš takový, jako bych řekla, oficiální, Guten Tag, jo, třeba u nějakýho oslovení, Meine Damen und Herren, jo, Vážení pánové, vážené dámy a tak, ale takový ten běžný výraz paní je Frau.

Table 4: Transcript from lesson A1 - Category 6: culture-specific: small-c culture knowledge

\subsubsection{Category 7: culture-specific: skills and behaviour}

This category was represented in lesson B3 (20 seconds). The pupils were supposed to react to the teacher's question: „Wie geht's dir?" and actually reacted to the question using "Danke, gut!".

In lesson A4 (30 seconds) the pupils were supposed to say what they would say to a friend on their birthday.

$00: 17: 10-00: 17: 40$

T: Hm, co mu popřála k narozeninám?

P: Hodně štěstí zdraví (singing).

T: Viel Glück und? To klasické, všechno nejlepší? Jak to vyjádříme?

$P:()$

T: To nevadí, jak řeknete všechno nejlepší k narozeninám?

P: Happy Birthday!

T: To všechno nejlepší! A.//

P: //Alles Gute!

T: //lles Gute!

Table 5: Transcript from lesson A4 - Category 7: culture-specific: skills and behaviour

\subsubsection{Category 9: other}

Category 9: other was represented in all of the lessons. The total teaching time for this category was 1,069 minutes and 51 seconds $(90 \%$ of the total teaching time). The extract that follows is from lesson F3 in which the teacher prepared the PowerPoint presentation about Vienna (see 4.2.2). However, in this extract a photograph of the pupils from Vienna was used and the pupils were asked, what their friends were doing in the picture and were supposed to write a sentence into their notebooks. As the pupils were sitting under a tree in the picture, it was not 
obvious, where the picture was taken and the pupils were supposed to describe it using general language, this category was coded as Category 9: other.

00:38:10-00:38:20

T: Übersetzt, bitte, diese Frage - Přeložte otázku. Was machen unsere

00:38:20-00:38:30

T: Freunde?

$P P:()$

T: Tak, řekni to! Co dělají naši

00:38:30-00:38:40

T: kamarádi//

PP: // kamarádi

T: tak. Každý z vás napíšete jednu větu do sešitu, co dělají. Vymyslíte větu německy.

Table 6: Transcript from lesson F3 - Category 9: other

\section{Conclusion}

The findings show that teachers of German mainly focus on the cognitive dimension of ICC in their teaching (118 minutes as opposed to 50 seconds devoted to the behavioural dimension if ICC). While the IRSE Video Study of English (Zerzová, 2012) proved, that teachers of English tend to focus on culture-specific topics (92\% of the teaching time devoted to ICC), the IRSE Video Study of German did not confirm this. However, the research sample was small (28 videotaped lessons) and in two lessons the teachers worked with the same topic (names of countries and continents), which explains the higher percentage of teaching time devoted to culture-general topics ( $57 \%$ of the teaching time devoted to developing ICC) as opposed to the findings from the IRSE Video Study of English (8\%). The focus on the cognitive component of ICC was present in both video studies. The opportunities do develop ICC represent rather one-sided focus neglecting the behavioural and affective component of ICC.

The findings of the IRSE Video Study of English proved that there were primarily receptive skills (reading and listening) practiced in the lessons, which serve very well for developing the cognitive component of ICC and that the productive skills (speaking and writing) were mainly used for revision of the subject matter (Zerzová \& Šebestová, 2014). It is probable that higher representation of the productive skills might bring better conditions for developing the behavioural and affective component of ICC together with higher representation of the target language in the lessons as skills needed for intercultural communication necessarily need to be practice in the target language. A parallel study in the IRSE Video Study of German of this kind has not been made, but it would be desirable if future research opted this way. However, although the language used in the 
lessons was not coded and thus we do not know what the percentage of the use of mother tongue in the lessons is, mere look at the extracts from the transcripts suggest that the use of the mother tongue in the lessons is very common and the proportion is representative of the whole sample.

The reasons explaining the state of ICC development in Czech lower-secondary schools may be found in foreign research (Dunnett et al., 1986; Met, 1993; Byram \& Morgan, 1994; Kelly, 2002; Guilherme, 2002; Sockett \& LePage, 2002; Lázár, 2003; Sercu, 2002a; Sercu, 2002b; Met, 1993) which suggests that teachers do not feel competent to develop the pupils' ICC and although research in the Czech Republic is very limited, there are studies that confirm the need to address ICC development of both teachers and pupils in teacher education (Zerzová, 2012; Kostková, 2012; Zerzová, 2017).

\section{References}

Bennett, M. J. (1986). A Developmental Approach to Training for Intercultural Sensitivity. International Journal for Intercultural Relations, 10(2), 179-196.

Bennett, J. M., Bennett, M. J., \& Allen, W. (2003). Developing intercultural competence in the language classroom. In D. L. Lange \& R. M. Paige (Eds.), Culture as the core: Perspectives on culture in second language learning (pp. 237-270). Greenwich, CT: Information Age Publishing.

Bočánková, M. (2006). Interkulturní výzkumy na katedře anglického jazyka. Acta Oeconomica Pragensia, 14(4), 9-17. Available at: http://www.vse.cz/aop/pdf/95.pdf

Brebera, P., \& Kostková, K. (2008). K možnostem zkoumání profesní kompetence učitele cizích jazyků v některých jejích doménách. In T. Janík (Ed.), Metodologické problémy výzkumu didaktických znalostí obsahu (pp. 51-64) . Brno: Paido.

Buttjes, D. (1995). Landeskunde-Didaktik und landeskundliches Curriculum. In K.-

R. Bausch, H. Christ, H.-J. Krumm (Eds.). Handbuch Fremdsprachenunterricht (pp. 142-149). Tübingen: Francke.

Byram, M., \& Morgan, C. (1994). Teaching-and-Learning Language-and-Culture. Clevedon: Multilingual Matters.

Byram, M. (1997). Teaching and Assessing Intercultural Communicative Competence. Clevedon: Multilingual Matters.

Carroll, J. B. (1963). A model of school learning. Teachers' College Record, 64(8), 723-733.

Doyle, W. (1983). Academic work. Review of Educational Research, 53(2), 159-199. Dunnett, S. C., Dubin, F., \& Lezberg, A. (1986). English language teaching from an intercultural perspective. In J. M. Valdes (Ed.), Culture bound: Bridging the Cultural Gap in Language Teaching (pp. 148-161). Cambridge: Cambridge University Press. 
Fantini, A. E. (2006). Exploring and assessing intercultural competence. [Závěrečná zpráva výzkumného projektu]. Available at: http://www.experiment.org/documents/FinalGSIResearchReport12.06.pdf

Göbel, K. (2007). Qualität im interkulturellen Englischunterricht. Eine Videostudie. Münster: Waxmann Verlag.

Guilherme, M. (2002). Critical Citizens for an intercultural world. Foreign language education as cultural politics. Clevedon: Multilingual Matters.

Hammer, M.R. (2009). The Intercultural Development Inventory: An Approach for assessing and building intercultural competence. In M.A. Moodian (Ed.), Contemporary leadership and intercultural competence: Exploring the crosscultural dynamics within organizations (pp. 203-108). Thousand Oaks, CA: Sage.

Hiebert, J., \& Wearne, D. (1993). Instructional tasks, classroom discourse, and students' learning in second-grade arithmetic. American Educational Research Journal, 30(2), 393-425.

Hladík, J. (2010). Výzkum vztahu kognitivní a afektivní dimenze multikulturních kompetencí. In Český pedagogický výzkum v mezinárodním kontextu. Sborník príspěvků XVII. ročníku celostátní konference ČAPV (pp. 355-361). Ostrava: Pedagogická fakulta Ostravské univerzity. [CD-ROM]

Hofstede, G., \& Hofstede, G. J. (2005). Cultures and organizations: Software of the mind. London: McGraw-Hill.

Huntington, S. P. (1996). The clash of civilizations and the remaking of world order. New York: Simon \& Schuster.

Janík, T., \& Miková, M. (2006). Videostudie: výzkum výuky založený na analýze videozáznamu. Brno: Paido.

Kelly, M., et al. (2002). The Training of Teachers of a Foreign Language: Developments in Europe. A Report to the European Commision Directorate General for Education and Culture. Available at: http://ec.europa.eu/education/languages/pdf/doc493_en.pdf

Kostková, K. (2010a). Teacher and Intercultural Communicative Competence as a challenge. In T. Janík, \& P. Knecht (Eds.), New Pathways in the Professional Development of Teachers (pp. 232-240). Wien, Münster: LIT Verlag.

Kostková, K. (2010b). Intercultural Communicative Competence - its development and assessment. In Challenges in Foreign Language Education (pp. 59-65). Bratislava, Slovakia.

Kostková, K. (2012). Rozvoj interkulturní komunikační kompetence. Brno: MuniPress.

Kramsch, C. (1993). Context and Culture in Language Teaching. Oxford: Oxford University Press.

Kubeš, M., Kurnický, R., \& Spillerová, D. (2004). Manažerské kompetence: Způsobilosti výjimečných manažerů. Praha: Grada.

Langner, M., et al. (1990). ABCD-Thesen zur Rolle der Landeskunde im 
Deutschunterricht. Fremdsprache Deutsch. Zeitschrift für die Praxis des Deutschunterrichts, 5, 60-61.

Lázár, I. (Ed.). (2003). Incorporating intercultural communicative competence in language teacher education. European Centre for Modern Languages: Council of Europe Publishing. Available at: http://www.ecml.at/documents/pub123bE2003_Lazar.pdf

Maňák, J. (2007). Kompetence ve struktuře kurikula. In D. Greger \& V. Ježková (Eds.), Školní vzdělávání: zahraniční trendy a inspirace (pp. 87-101). Praha: Karolinum.

McDonnell, L. M. (1995). Opportunity to learn as a research concept and a policy instrument. Educational Evaluation and Policy Analysis, 17(3), 305-322.

Met, M. (1993). Teaching language and culture: A view from the schools. In J. E. Alatis (Ed.), Language, Communication and Social Meaning (s. 259-274). Washington: Georgetown University Press.

Najvar, P., Najvarová, V., Janík, T., \& Šebestová, S. (2011). Videostudie v pedagogickém výzkumu. Brno: Paido.

Najvar, P., Najvarová, V., Soběslavská, V., Šebestová, S., Vlčková, K., \& Zerzová, J. (2008). CPV videostudie anglického jazyka: sběr dat a zamýšlené analýzy. Orbis scholae, 2(1), 73-91.

Navrátil, P. (2002). Výzkum interetnických vztahů. Brno: Phare. Výzkumná zpráva. Nünnig, V., \& Nünnig, A. (2000). British Cultural Studies konkret. 10 Leitkonzepte für einen innovativen Kulturunterricht. Der Fremdsprachliche Unterricht English, 1, 6-9.

Pauldrach, A. (1990). Eine unendliche Geschichte. Anmerkungen zur Situation der Landeskunde in den 90er Jahren. Fremdsprache Deutsch. Zeitschrift für die Praxis des Deutschunterrichts, 6, 6-15. Ismaning: Max Hueber Verlag.

Pešková, K. (2012). Vizuální prostředky pro výuku reálií v učebnicích němčiny. Brno: MuniPress.

Píšová, M. (2005). Klinický rok: procesy profesního rozvoje studentů učitelství a jejich podpora. Pardubice: Univerzita Pardubice, Fakulta humanitních studií.

Průcha, J. (2001). Multikulturní výchova. Teorie - praxe - výzkum. Praha: ISV nakladatelství.

Průcha, J. (2006). Multikulturní výchova: př́ručka (nejen) pro učitele. Praha: Triton. Reid, E. (2014). Intercultural Aspects in Teaching English at Primary Schools. Peter Lang Edition.

Rimmele, R. (2002). Videograph. Multimedia-Player zur Kodierung von Videos. Kiel: IPN.

Seidel, T., Prenzel, M., Duit, R., \& Lehrke, M. (Eds.). (2003). Technischer Bericht zur Videostudie „Lehr-Lern-Prozesse im Physikunterricht“. Kiel: IPN.

Seletzky, M. (1996). A process-oriented and learner-centered approach to the teaching of 'Landeskunde' in the German-language classroom. In H. Christ and 
M. Legutke (Eds.). Fremde Texte Verstehen: Festschrift für Lothar Bredella zum 60. Geburtstag. Tübingen: G. Narr.

Sercu, L. (2002a). Autonomous learning and the acquisition of intercultural communicative competence: Some implications for course development. Language, Culture and Curriculum, 15(1), 61-74.

Sercu, L. (2002b). Implementing intercultural foreign language education. Belgian, Danish and British teachers' professional self-concepts and teaching practices compared. Language Awareness, 16(3), 150-165.

Skalková, J. (2007). Obecná didaktika. Praha: Grada.

Souhrnné poznatky o podpoře a rozvoji výuky cizích jazyků $v$ předškolním, základním a středním vzdělávání v období let 2006-2009. (2010). Praha: Česká školní inspekce. Available at: http://www.csicr.cz/cz/85027-podpora-arozvoj-vyuky-cizich-jazyku

Timm, J.-P. (Ed.). (1998). Englisch lernen und lehren: Didaktik des Englischunterrichts. Berlin: Cornelsen Verlag.

Tomalin, B., \& Stempleski, S. (1993). Cultural awareness. Oxford: Oxford University Press.

Triandis, H. C. (1989). Intercultural education and training. In P. Funke (Ed.), Understanding the USA: A cross-cultural perspective (pp. 305-322). Tübingen: Narr Verlag.

Zerzová, J. (2012). Interkulturní komunikační kompetence a její rozvíjení v hodinách anglického jazyka na 2. stupni ŽS. Brno: MuniPress. doi:10.5817/CZ.MUNI.M210-6824-2014.

Zerzová, J. \& Šebestová, S. (2014). Př́ležitosti k rozvíjení interkulturní komunikační kompetence v kontextu řečových dovedností: IVŠV videostudie anglického jazyka. Pedagogická orientace, 24(3), 394-422. doi:10.5817/PedOr2014-3-394.

Zerzová, J., Šamalová, M. \& Karpetová, M. (2017). Kulturní aspekty angličtiny jako mezinárodního jazyka v učebnicích angličtiny. In M. Pešková \& K. Kubíková. Rozvíjení interkulturní komunikační kompetence ve výuce cizích jazyků. Plzeň: Západočeská univerzita v Plzni, 45-57.

Zerzová, J. (2017). Výzkum rozvoje interkulturní kompetence studentů anglického jazyka pomocí Intercultural Development Inventory®, version 3. Cizí jazyky, 60 (4), 3-12. Univerzita Karlova.

Zlatníček, P. (2014). Zjišttování kvality výuky cizího jazyka: Vývoj a aplikace nástroje pro posuzování míry zastoupení vybraných komponent a charakteristik kvality výuky. Disertační práce. Brno: Masarykova Universita. 


\section{Contact}

Mgr. Jana Zerzová M.A., Ph.D.

Department of English Language and Literature

Faculty of Education, Masaryk University

Poříćí 7, 60300 Brno

zerzova@mail.muni.cz 